IN THE

\title{
Supreme Court of the afnited States
}

DONALD J. TRUMP, et al.,

Petitioners,

$\mathrm{v}$.

STATE OF HAWAII, et al.,

Respondents.

On Writ of Certiorari to the United States Court of Appeals for the Ninth Circuit

\section{BRIEF OF AMICI CURIAE FORMER NATIONAL SECURITY OFFICIALS IN SUPPORT OF RESPONDENTS}

PHILLIP SPECTOR

MESSING \& SPECTOR LLP

1200 Steuart Street

\#2112

Baltimore, MD 21230

(202) 277-8173

JONATHAN FREIMAN

TAHLIA TOWNSEND

WIGGIN AND DANA LLP

265 Church Street

P.O. Box 1832

New Haven, CT 06508-1832

(203) 498-4584
HAROLD HONGJU KOH

Counsel of Record

MATTHEW S. BLUMENTHAL

RULE OF LAW CLINIC

YALE LAW SCHOOL

127 Wall Street

P.O. Box 208215

New Haven, CT 06520

(203) 432-4932

harold.koh@ylsclinics.org

WILLIAM J. MURPHY

JOHN J. CONNOLLY

ZUCKERMAN SPAEDER LLP

100 E. Pratt St.

Suite 2440

Baltimore, MD 21202

(410) 332-0444

Counsel for Amici Curiae

March 30, 2018

WILSON-EPES PRINTING Co., INC. - (202) 789-0096 - WASHINGTON, D. C. 20002 
TABLE OF CONTENTS

\section{Page}

TABLE OF AUTHORITIES ....................................ii

STATEMENT OF INTEREST................................. 1

SUMMARY OF ARGUMENT ................................. 2

ARGUMENT …...................................................... 4

I. This Court Should Not Reflexively Defer to Petitioners' Claims of National Security and Foreign Policy Judgment

II. Petitioners' Actions Do Not Merit This Court's

Deference

A. The Orders did not emerge from the considered judgment of national security or foreign policy officials.

B. The Orders do not advance the national security or foreign policy interests of the United States, and in fact do serious harm to those interests

1. The Orders do not advance the national security or foreign policy interests of the United States.....

2. The Orders do serious damage to the national security and foreign policy interests of the United States

C. Petitioners are unable to offer a credible national security or foreign policy rationale for the Orders .................................................. 28

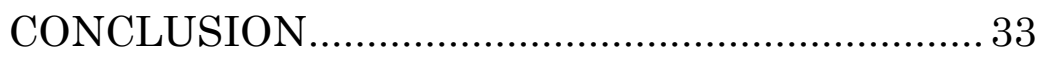

APPENDIX: List of Amici Curiae ......................... A-1 
ii

\section{TABLE OF AUTHORITIES}

\section{Page(s)}

\section{CASES}

Boumediene v. Bush, 553 U.S. 723 (2008) ................5

Chicago \& S. Air Lines, Inc., 333 U.S. 103 (1948) ...................................................6

Goldman v. Weinberger, 475 U.S. 503 (1986) ........... 5

Haig v. Agee, 453 U.S. 280 (1981) ........................6

Holder v. Humanitarian Law Project, 561 U.S.

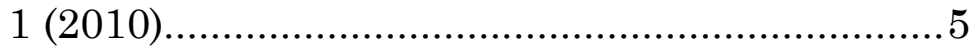

Hunter v. Underwood, 471 U.S. 222 (1985) ............. 14

Kleindienst v. Mandel, 408 U.S. 753 (1972).............5

McCreary County v. ACLU of Kentucky, 545 U.S. 844 (2005) .................................... 14

Reno v. American-Arab Anti-Discrimination

Comm., 525 U.S. 471 (1999)...........................6

U.S. v. Fordice, 505 U.S. 717 (1992) ................13, 14

Vill. Of Arlington Heights v. Metro. Hous.

Dev. Corp., 429 U.S. 252 (1977) ....................... 12

Winter v. Nat. Res. Def. Council, 555 U.S. 7 (2008) .........................................5

Zivotofsky ex rel. Zivotofsky v. Kerry, 135 S.Ct. 2076 (2015)

\section{STATUTES, RULES AND REGULATIONS}

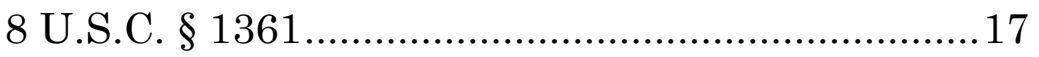

8 U.S.C. $\S 1182(\mathrm{f})$............................................. 8

Exec. Order No. 11,030, 27 Fed. Reg. 5,847

(Jun. 19, 1962)......................................... 10

Exec. Order 12,172, 44 Fed. Reg. 67,947

(Nov. 26, 1979). 
Exec. Order No. 12,324, 46 Fed. Reg. 48,109

(Sept. 29, 1981)

Exec. Order No. 12,807, 57 Fed. Reg. 23,133

(May 24, 1992)

Exec. Order No. 13,694, 80 Fed. Reg. 18,077

(Apr. 1, 2015)

Exec. Order No. 13,726, 81 Fed. Reg. 23,559

(Apr. 19, 2016)

Exec. Order No. 13,769, 82 Fed. Reg. 8977

(Feb. 1, 2017) passim

Exec. Order No. 13,780, 82 Fed. Reg. 13,209

(Mar. 9, 2017).

passim

Proclamation No. 6,958, 61 Fed. Reg.

60,007 (Nov. 22, 1996)

Proclamation No. 5,517, 51 Fed. Reg. 30,470

(Aug. 26, 1986).

Proclamation No. 9,645 (Sept. 24, 2017)..........passim

\section{MISCELLANEOUS}

Adams Nager, et al., The Demographics of

Innovation in the United States, Information

Technology \& Innovation Foundation (Feb.

2016)

Alex Nowrasteh, 42 Percent of 'TerrorismRelated' Convictions Aren't for Terrorism, Cato Institute (Mar. 6, 2017)

Alex Nowrasteh, Terrorism and Immigration: A Risk Analysis, Cato Institute (Sept. 13, 2016)

Alex Nowrasteh, President Trump's New Travel Executive Order Has Little National Security Justification, Cato Institute: Cato at Liberty (Sept. 25, 2017) 
Andorra Bruno, Cong. Research Serv., R43725, Iraqi and Afghan Special Immigrant Visa

Programs (Feb. 26, 2016) 26

Andrew Higgins, Terrorism Response Puts Belgium in a Harsh Light, N.Y. Times (Nov. 24, 2015)....

Charles Babcock, Carter's Visa Crackdown Won't Hurt Immediately, N.Y. Times (Apr. 9, 1980)

Conor Gaffey, After Trump's Travel Ban, Chad Pulls Troops from Boko Haram Fight in Niger, Newsweek (Oct. 13, 2017)

David Bier, Prior Presidents' "Travel Bans" Are Different From President Trump's Ban, Cato Institute: Cato at Liberty (Nov. 16, 2017).....

Decl. of Brigadier General Jay Hood, Hamdan v. Rumsfeld, 548 U.S. 557 (2006)

Decl. of Jennifer B. Higgins in Support of Defendant's Opposition to Plaintiff Joseph Doe's Motion for Preliminary Injunction, Doe v. Trump, No. 2:17-cv-00178 JLR (W.D. Wash. 2017)

Decl. by Brigadier General Jay Hood, Hamdan v. Rumsfeld, 341 F.Supp.2d 152 (D.D.C. 2004) (No. 1:04-cv-01519).

Donald J. Trump (@realDonaldTrump), Twitter (September 15, 2017, post uploaded at 3:54 a.m.)

Edward Alden, The Closing of the American Border (2008) 8

Evan Perez et al., Inside the Confusion of the Trump Executive Order and Travel Ban, CNN (Jan. 30, 2017) 9,11 
Felicia Schwartz \& Ben Kesling, Countries Under U.S. Entry Ban Aren't Main Sources of Terror Attacks, Wall St. J. (Jan. 29, 2017) ...... 18

Gerald M. Boyd, Reagan Acts to Tighten Trade Embargo of Cuba, N.Y. Times (Aug. 23, 1986)

Henry B. Hogue, Cong. Research Serv., Presidential Transition Act: Provisions and Funding (2016)

Helene Cooper et al., Chad's Inclusion in Travel Ban Could Jeopardize American Interests, Officials Say, N.Y. Times (Sept. 26, 2017)

Jeffrey Gettleman, State Dep't Dissent Cable on Trump's Ban Draws 1,000 Signatures, N.Y. Times (Jan. 31, 2017)

Jeremy Diamond, Trump Rails Against Court Ruling Blocking Travel Ban, CNN (Mar. 15, 2017).

Joby Warrick, Jihadist Groups Hail Trump's Travel Ban as a Victory, Wash. Post (Jan. 29, 2017)

Jon Finer, Sorry, Mr. President: The Obama Administration Did Nothing Similar to Your Immigration Ban, Foreign Policy (Jan. 30, 2017)

Jonathan Allen \& Brendan O'Brien, How

Trump's Abrupt Immigration Ban Sowed Confusion at Airports, Agencies, Reuters (Jan. 29, 2017) 9,10

Karoun Demirjian \& Jerry Markon, Obama Administration Rolls Out New Visa Waiver Program Rules in Wake of Terror Attacks, Wash. Post (Jan. 21, 2016) 
Kevin Sieff, Why Did the U.S. Travel Ban Add Count Terrorism Partner Chad? No One Seems Quite Sure, Wash. Post (Sept. 25, 2017).

Krishnadev Calamur, Why Was Chad Included in the New Travel Ban?, The Atlantic (Sept. $26,2017)$.

Kristina Cooke \& Joseph Ax, U.S. Officials Say American Muslims Do Report Extremist Threats, Reuters (Jun. 16, 2016).

Letter from Jeffrey B. Sessions, Att'y Gen. and John Francis Kelly, Sec'y of Homeland Sec. to President Donald J. Trump, Mar. 6, 2017. 19,29

Letter from Mary K. Waters, Assistant Sec'y, Legislative Affairs, to Chris Van Hollen, Senator (Feb. 22, 2018)

Lisa Daniels, Nora Ellingsen, \& Benjamin Wittes, Trump Repeats His Lies About Terrorism, Immigration and Justice Department Data, Lawfare (Jan. 16, 2018) ........ 18

Lorenzo Vidino \& Seamus Hughes, ISIS in America: From Retweets to Raqqa, Geo. Wash. Program on Extremism 7 (Dec. 2015) ..... 18

Mark Hosenball, U.S. Frustration Simmers Over Belgium's Struggle with Militant Threat, Reuters (Mar. 24, 2016)...

Mallory Moench, Banned From the U.S. Due to Terrorist Threats, Yemenis Are Themselves the Victims of Attacks, The Intercept (Feb. 18, 2018)

Matthew Nussbaum et al., White House Creates Confusion About Future of Trump's Travel Ban, Politico (Feb. 21, 2017) 
vii

Michael D. Shear \& Ron Nixon, How Trump's

Rush to Enact an Immigration Ban

Unleashed Global Chaos, N.Y. Times

(Jan. 29, 2017)

$9,10,11$

Michael V. Hayden, Former CIA Chief:

Trump's Travel Ban Hurts American

Spies - and America, Wash. Post

(Feb. 5, 2017)

Molly Redden, Trump Powers "Will Not be

Questioned" on Immigration, Senior

Official Says, The Guardian (Feb. 12, 2007) ......19

Notice of In Camera, Ex Parte Lodging of

Report, State of Hawai'i v. Trump,

No. 17-cv-00050 (Dec. 13, 2017).

Nora Ellingsen, It's Not Foreigners Who Are

Plotting Here: What the Data Really Show,

Lawfare (Feb. 7, 2017)

Nora Ellingsen \& Lisa Daniels, What the Data Really Show about Terrorists Who "Came Here,” Lawfare (Apr. 11, 2017).

Nora Ellingsen \& Benjamin Wittes, Anatomy

of a Presidential Untruth: What Data

Did the Justice Department Really

Provide the White House?, Lawfare

(Feb. 12, 2018)

19,20

Office of the Inspector Gen., U.S. Dep't of

Homeland Sec., OIG-18-37, DHS Implementa-

tion of Executive Order \#13769 "Protecting the Nation from Foreign Terrorist Entry Into

the United States" (Jan. 18, 2018).

Oral Argument in Int'l Refugee Assistance

Project v. Trump, No. 17-1351 (4th Cir.

May 8, 2017) 
viii

Patrick O'Neill, How Academics Are Helping Cybersecurity Students Overcome Trump's Immigration Order, Cyberscoop (Jan. 30, 2017)

Peter Bergen et al., Terrorism in America After 9/11, New America Foundation 18

Protecting the Nation From Foreign Terrorist Entry Into the United States: Initial Section 11 Report (Jan. 2018)

Rick Noack et al., Britain and U.S. ban most electronic devices in cabins on flights from several Muslim-majority countries, Wash. Post (Mar. 21, 2017)

Shirin Sinnar, More Misleading Claims on Immigrants and Terrorism, Just Security (Mar. 4, 2017).

Ten Years After 9/11: Preventing Terrorist Travel: Hearing Before the S. Comm. on Homeland Security and Governmental Affairs, 112th Cong. 122-127 (2011)

The International Implications of Trump's Refugee Ban, NPR (Jan. 29, 2017).

The Security of U.S. Visa Programs: Hearing Before the S. Comm. on Homeland Sec. \& Governmental Affairs, 114th Cong. (2016)

Thomas R. Eldridge, et al., 9/11 and Terrorist Travel: A Staff Report of the National Commission on Terrorist Attacks Upon the United States 151-54 (2004) 8

Unclassified Declaration in Support of Formal Claim of State Secrets Privilege by James R. Clapper, Director of Nat'l Intelligence, $A l$ Aulaqi v. Obama, 727 F.Supp.2d 1 (D.D.C. 2010) (No. 1:10-cv-01469). 
ix

U.S. Dep't of Homeland Sec., Citizenship Likely an Unreliable Indicator of Terrorist Threat to the United States

U.S. Dep't of Homeland Sec., Fact Sheet: Aviation Security Enhancements for Select Last Point of Departure Airports with Commercial Flights to the United States (Mar. 21, 2017)

U.S. Dep't of Homeland Sec., DHS Announces Further Travel Restrictions for the Visa Waiver Program (Feb. 18, 2016)

U.S. Dep't of State, Bureau of Population, Refugees, and Migration, Refugee Arrivals, Interactive Reporting (2011).... 26

White House, Fact Sheet: Visa Waiver Program Enhancements (Nov. 30, 2015)............................26

William Glaberson \& Helene Cooper, Obama's Plan to Close Prison at Guantanamo May Take One Year, N.Y. Times (Jan. 12, 2009) 


\section{STATEMENT OF INTEREST ${ }^{1}$}

Amici curiae are former national security, foreign policy, intelligence, and other public officials who have worked on security matters at the senior-most levels of the United States government. ${ }^{2}$ Amici have held the highest security clearances in the U.S. government. They have collectively devoted their careers to combatting the various terrorist threats that the United States faces in an increasingly dangerous and dynamic world. A number of them have served in leadership roles in the administrations of Presidents from both major political parties. Many were current on active intelligence regarding credible terrorist threat streams directed against the United States as recently as one week before the issuance of the original January 27, 2017 Executive Order on "Protecting the Nation from Foreign Terrorist Entry into the United States" (“Travel Ban 1.0"). Some were current around the time of the identically titled March 6, 2017 Executive Order ("Travel Ban 2.0"), mere months before the September 24, 2017 Presidential Proclamation Enhancing Vetting Capabilities and Processes for Detecting Attempted Entry into the United States by Terrorists or Other Public-Safety Threats ("Travel Ban 3.0") (collectively, the "Orders"). Amici write to offer the Court their perspective on the many substantial national security and foreign policy issues raised by this case.

\footnotetext{
${ }^{1}$ No counsel for a party to this case authored this brief in whole or in part, and no such counsel or party contributed monetarily to the preparation or submission of any portion of this brief. Amici received consent from Respondents to file this brief. Petitioners provided blanket consent to file amicus curiae briefs.
}

2 A complete list of signatories can be found in the Appendix. 


\section{SUMMARY OF ARGUMENT}

Amici agree that in order to keep our country safe from terrorist threats, the U.S. government must gather all credible evidence to thwart those threats before they ripen. Through the years, amici have worked individually and collectively to develop national security policies that have: (1) responded to specific, credible threats based on individualized information, (2) rested on the best available intelligence, and (3) been subject to thorough interagency review. The three sweeping Travel Bans that the President has issued over the past fourteen months do not rest on such carefully tailored grounds, but rather: (1) are overbroad, blanket entry bans based on national origin, (2) are not supported by any intelligence that Petitioners have cited or of which amici are aware, and (3) did not emerge from a careful interagency policy and legal review involving the considered judgment of national security and foreign policy officials.

Petitioners nonetheless seek from this Court what they describe as the "deference owed to the Executive's foreign-policy and national-security judgments." ${ }^{3}$ As former senior national security officials, amici greatly value expertise and judgment in the development of security policy and appreciate the importance of courts deferring to that expertise and judgment in appropriate cases. Amici write to explain why these Orders should not be deemed an exercise of the Executive's foreign policy and national security judgment that is deserving of this Court's deference.

First, the Orders did not emerge from meaningful Executive Branch judgment and deliberation. Travel Ban 1.0 was not vetted through the relevant

3 Pet'rs' Br. 36. 
Executive agencies, and took the President's own national security and foreign policy officials by surprise. Indeed, the Executive's national security and foreign policy experts played no role at all in the development of Travel Ban 1.0. Travel Bans 2.0 and 3.0 so closely mirror the original ban in form and substance that any additional "process" the Government now cites cannot dispel this original sin.

Second, the Orders radically depart from the Executive's consistent approach to border security across multiple administrations. For compelling national security reasons, prior administrations have adopted rigorous individualized vetting based on cognizable intelligence, rather than blanket, national originbased bans. Overwhelming evidence demonstrates that the Proclamation's overbroad suspension of travel has not only failed to advance our national security or foreign policy interests, but is seriously damaging those interests.

Third, Petitioners have been unable to articulate a credible-let alone compelling —national security or foreign policy need for the Orders. Petitioners' rationale for a sweeping national-origin based ban on travel has shifted with each new Order. Petitioners have not come forward with a sworn declaration from a single Executive official who is willing to describe the national security-based need for the Orders, or the process that led to their adoption. Nor have Petitioners pointed to any other evidence of a security imperative that could remotely justify their unprecedented actions. And Petitioners' own dilatory actions in the wake of Travel Ban 1.0 show that even they never took seriously their assertions of national security urgency.

Particularly when considered in light of the President and his advisors' well-publicized statements 
calling for a "Muslim Ban," these factors undermine any claim that this was a credible exercise of the Executive's foreign policy and national security judgment. While the Orders at issue in this case may be about national security, they do not reflect a bona fide national security judgment that merits this Court's deference. Were this Court to afford the Executive the benefits of deference here, it is difficult to imagine a case in which national security deference would be withheld. It is the province and duty of this Court to say what the law is, not to act as a national security rubber stamp. The uncontested record establishes that for fourteen months, as the Administration sought to promulgate and then justify these bans, our nation's security was hardly deliberated at all, let alone through the appropriate channels. This Court should not allow Petitioners to shield Travel Ban 3.0 from meaningful judicial review by cloaking discrimination in a thin veil of "national security."

\section{ARGUMENT \\ I. This Court Should Not Reflexively Defer to Petitioners' Claims of National Security and Foreign Policy Judgment.}

Petitioners' defense of the Orders rests heavily on principles of deference to the national security and foreign policy judgment of Executive Branch officials. ${ }^{4}$

\footnotetext{
${ }^{4}$ See, e.g., Pet'rs' Br. 36 ('The court of appeals erred by supplanting the deference owed to the Executive's foreign-policy and national-security judgments with a standard of searching judicial scrutiny.”). See generally Pet'rs' Br. 19-22 (arguing that national security deference counsels in favor of an expansive reading of the rule of non-reviewability); Pet'rs' Br. 36, 39-40 (arguing that "[d] eference is especially warranted" in the statutory inquiry in this case due to the Executive's exercise of national security judgment); Pet'rs' Br. 58-60, 64-65 (arguing that the Executive's
} 
However, Petitioners never actually explain why this record warrants granting such deference here. Instead, they simply assume that because this case involves a national security or foreign policy issue, this Court's deference must reflexively follow. But a better view of this Court's jurisprudence is that national security deference requires some threshold showing that professional judgment was actually exercised. Such a showing has not been made here.

This Court has traditionally deferred to (1) an exercise of "considered professional judgment" by national security officials, ${ }^{5}$ (2) acting on intelligence showing a bona fide security threat, ${ }^{6}$ (3) where the government must speak and act with a consistent voice, ${ }^{7}$ and especially where it must act (4) on the

exercise of national security judgment is a reason for a "deferential" approach to the Establishment Clause and a narrow reading of Kleindienst v. Mandel, 408 U.S. 753, 770 (1972)).

${ }^{5}$ Goldman v. Weinberger, 475 U.S. 503, 507 (1986); see also Winter v. Nat. Res. Def. Council, 555 U.S. 7, 24 (2008) (giving "great deference to the professional judgment of military authorities") (quoting Goldman).

${ }^{6}$ Holder v. Humanitarian Law Project, 561 U.S. 1, 34 (2010) ("One reason for that respect is that national security and foreign policy concerns arise in connection with efforts to confront evolving threats in an area where information can be difficult to obtain and the impact of certain conduct difficult to assess."); see also Boumediene v. Bush, 553 U.S. 723, 797 (2008) (granting deference because "the Members of this Court * * * [do not] begin the day with briefings that may describe new and serious threats to our Nation").

${ }^{7}$ Zivotofsky ex rel. Zivotofsky v. Kerry, 135 S.Ct. 2076, 2086, 2091 (2015) (describing the need to speak "with one voice" and "have a single policy" as reasons to give the President broad authority over foreign affairs and the recognition power) (quotation omitted)). 
basis of classified information, ${ }^{8}$ and (5) with particular urgency. ${ }^{9}$

None of those conditions is present here. Petitioners do not-and cannot_cite a single case where deference was afforded the Executive for an action that (1) did not emerge from the considered judgment of Executive officials at all, ${ }^{10}(2)$ is not a credible response to a bona fide security threat, ${ }^{11}$ (3) is premised on ever-shifting rather than consistent rationales, ${ }^{12}$ and (4) where the government has failed to come forward with sworn testimony or any other information evincing a security need for the Orders, in either classified or unclassified form, ${ }^{13}$ (5) and the government belies any claim of urgency through its own leisurely implementation of its Orders. ${ }^{14}$

8 Haig v. Agee, 453 U.S. 280, 307-308 (1981) ("[The President] has his confidential sources of information. He has his agents in the form of diplomatic, consular and other officials. Secrecy in respect of information gathered by them may be highly necessary, and the premature disclosure of it productive of harmful results.") (quoting United States v. Curtiss-Wright Exp. Corp., 299 U.S. 304, 320 (1936)); Chicago \& S. Air Lines, Inc., 333 U.S. 103, 111 (1948) (deference is appropriate because national security decisions are often "properly held secret"). Here, Petitioners fail to come forward with evidence of a particularized threat from nationals of the listed countries, not because the information is secret, but because even their own agencies acknowledge it does not exist. See infra notes 47, 75-80 and accompanying text.

9 Reno v. American-Arab Anti-Discrimination Comm., 525 U.S. 471, 490-491 (1999) (identifying "the potential for delay" as reason for deference to the Executive in immigration matters).

10 See infra notes 15-35 and accompanying text.

11 See infra notes 36-70 and accompanying text.

12 See infra notes 71-74 and accompanying text.

13 See infra notes 75-80 and accompanying text.

${ }^{14}$ See infra notes 81-82 and accompanying text. 
In each of these respects, this case lies as far outside the heartland of this Court's jurisprudence of national security deference as one could imagine.

\section{Petitioners' Actions Do Not Merit This Court's Deference.}

\section{A. The Orders did not emerge from the con- sidered judgment of national security or foreign policy officials.}

The process that produced Travel Ban 1.0 departed dramatically from the traditional national security policy-making process, with little to no consultation or scrutiny across the Departments of State, Justice, Homeland Security, or the intelligence community. In both form and substance, Travel Bans 2.0 and 3.0 so closely tracked the original ban that the lingering discriminatory intent was never dispelled.

In every recent administration, Presidents considering an important change to immigration policy have followed an interagency review process, in which many of the amici have participated. That process allows experienced national security professionals to ensure that all relevant uncertainties are addressed by policy and legal experts, appropriate preparations are made for implementation, and any potential risks are effectively identified and mitigated.

The continuity of sound national security policy depends on the input and interaction of career, nonpolitical staff across the civil service, diplomatic corps, intelligence community, and the military. Before recommendations are submitted to the President, the National Security Council oversees a legal and policy process that typically includes: a review by the career professionals in those institutions of the U.S. government charged with implementing an order; a review 
by the career lawyers in those institutions to ensure legality and consistency in interpretation; and a policy review among senior leadership across all relevant agencies, including Deputies and Principals at the cabinet level. ${ }^{15}$ For policies impacting visa issuance for specific countries, the contribution of relevant Ambassadors and embassy country teams are also crucial for implementation and liaising with foreign governments.

This sustained practice of interagency deliberation has been followed even - and especially_in times of national emergency to set temporary exclusions or establish criteria for admission to the United States. In the immediate aftermath of the September 11, 2001 attacks, officials across the Bush Administration's national security agencies considered whether the President should invoke 8 U.S.C. $§ 1182(\mathrm{f})$ - the very same provision that Petitioners cite here-to bar certain immigrants or take other actions to secure the border. ${ }^{16}$ The reexamination of the Iraqi refugee vetting system in $2011^{17}$ and the security reforms to the Visa Waiver Program in 2015-2016 18 involved similar interagency consultation.

\footnotetext{
15 This is true whether or not the executive orders were issued at the start of a new presidency. See, e.g., Henry B. Hogue, Cong. Research Serv., RS22979, Presidential Transition Act: Provisions and Funding (2016); William Glaberson \& Helene Cooper, Obama's Plan to Close Prison at Guantanamo May Take Year, N.Y. Times (Jan. 12, 2009).

${ }^{16}$ See, e.g., Thomas R. Eldridge et al., 9/11 and Terrorist Travel: Staff Report of the National Commission on Terrorist Attacks Upon the United States 151-154 (2004); Edward Alden, The Closing of the American Border 104-106 (2008).

17 See infra notes 66-68 and accompanying text.

18 See infra notes 69-70 and accompanying text.
} 
The process that produced Travel Ban 1.0 deviated sharply from this standard practice. Collectively, amici are aware of no intragovernmental process that was underway before January 20, 2017 to change current immigration vetting procedures. According to extensive reporting, subsequent government reviews, and information available to amici, Petitioners followed no such interagency review in producing Travel Ban 1.0. The Order received little, if any, advance scrutiny by the Departments of State, Justice, Homeland Security, or the intelligence community. ${ }^{19}$ Nor, apparently, did the White House consult officials from any of the seven agencies tasked with enforcing immigration laws, much less the congressional committees and subcommittees that oversee them. ${ }^{20}$

Travel Ban 1.0 took even the President's own senior-most national security officials by surprise. The then-Secretary of Homeland Security reportedly received his first full briefing on the final Order just as

19 Jonathan Allen \& Brendan O'Brien, How Trump's Abrupt Immigration Ban Sowed Confusion at Airports, Agencies, Reuters (Jan. 29, 2017); Evan Perez et al., Inside the Confusion of the Trump Executive Order and Travel Ban, CNN (Jan. 30, 2017); Michael D. Shear \& Ron Nixon, How Trump's Rush to Enact an Immigration Ban Unleashed Global Chaos, N.Y. Times (Jan. 29, 2017).

${ }^{20}$ Office of the Inspector Gen., U.S. Dep't of Homeland Sec., OIG18-37, DHS Implementation of Executive Order \#13769 "Protecting the Nation from Foreign Terrorist Entry Into the United States" 5 (Jan. 18, 2018) [hereinafter OIG Report] (explaining that "DHS and its components had no opportunity to provide expert input in drafting the EO," and were "largely caught by surprise" as the Order was issued). Customs and border officials reported that their superiors had "practically no advance notice" of the Order and could not provide clear guidance about the new policy. OIG Report, supra; Shear \& Nixon, supra note 19; Allen \& O’Brien, supra note 19. 
the President was signing it. ${ }^{21}$ The Secretary of Defense was neither consulted during the drafting of the Order nor given an opportunity to provide input. ${ }^{22}$ The State Department was so excluded from the process that nearly all its officials first heard of the Order through the media, and within hours generated a dissent channel cable objecting to it that was signed by over 1,000 career officials. ${ }^{23}$ Amici include former senior U.S. diplomats who held posts at the time that Travel Ban 1.0 was issued; they first found out about the Order from news reports.

Equally telling, Travel Ban 1.0 was apparently issued without even the ordinary interagency legal process for review of Executive Orders. In recent history, administrations of both political parties have followed a protocol of submitting proposed Executive Orders to the Attorney General, the Justice Department's Office of Legal Counsel ("OLC") and all other agency legal offices involved with enforcing the law. ${ }^{24}$ A legal review by multiple agencies helps to identify potentially unforeseen implications of an order, determine the lawfulness of the proposed action, and analyze

21 Shear \& Nixon, supra note 19 ("As President Trump signed a sweeping executive order on Friday, shutting the borders to refugees and others from seven largely Muslim countries, the secretary of homeland security was on a White House conference call getting his first full briefing on the global shift in policy.").

22 Shear \& Nixon, supra note 19 (Secretary of Defense "Mattis, according to administration officials familiar with the deliberations, was not consulted by the White House during the preparation of the order and was not given an opportunity to provide input while the order was being drafted.").

${ }^{23}$ Allen \& O'Brien, supra note 19; Jeffrey Gettleman, State Dep't Dissent Cable on Trump's Ban Draws 1,000 Signatures, N.Y. Times (Jan. 31, 2017).

${ }^{24}$ See Exec. Order No. 11,030, 27 Fed. Reg. 5847 (Jun. 19, 1962). 
whether the proposed language has established legal meaning that can be interpreted consistently with other laws and regulations. Here, the White House never asked the Department of Homeland Security for legal review in advance of the promulgation of the Order, so the Department "was left making a legal analysis on the order after [President] Trump signed it."25

The aberrant process that produced these Orders becomes even clearer when contrasted with the steps this very Administration has taken in forming other national security policies. In March 2017, the Trump Administration announced that all personal electronic devices larger than a cell phone must be placed in checked baggage for direct flights from ten international airports to the United States (the "Laptop Ban"). ${ }^{26}$ According to public reporting and amici who were present in the Administration at the time, the Laptop Ban responded to a security threat identified by the Department of Homeland Security and other agencies based on available intelligence; it emerged from a deliberative process involving a range of national security officials; and it was rolled out with consistent instructions and explanations to our implementing agencies, our diplomatic partners and the American people. ${ }^{27}$ Without commenting on its merits, the Laptop Ban represents an example-from this Administration—of a "bottom-up" measure developed

25 Shear \& Nixon, supra note 19; Perez et al., supra note 19 (emphasis added).

26 U.S. Dep't of Homeland Sec., Fact Sheet: Aviation Security Enhancements for Select Last Point of Departure Airports with Commercial Flights to the United States (Mar. 21, 2017).

27 See, e.g., ibid.; Rick Noack et al., Britain and U.S. ban most electronic devices in cabins on flights from several Muslim-majority countries, Wash. Post (Mar. 21, 2017). 
by the relevant national security agencies in response to a threat. The Travel Bans, by contrast, constituted a "top-down" measure looking for a threat to justify them.

More than a year later, Petitioners remain unable to offer any evidence that the country-based approach mandated by the Orders emerged from the considered professional judgment of national security experts from across any of the multiple affected agencies. In fact, internal government documents reveal just the opposite. When the new administration asked DHS officials to identify the terrorist threat from the countries listed in Travel Ban 1.0, their written answer concluded-directly contrary to the assumptions underlying the Orders-that "country of citizenship is unlikely to be a reliable indicator of potential terrorist activity" and that few of the countries listed in the Ban are in fact home to terrorist groups that threaten the United States. ${ }^{28}$

As this Court noted in Vill. of Arlington Heights v. Metro. Hous. Dev. Corp., 429 U.S. 252, 267 (1977), "[d]epartures from the normal procedural sequence *** might afford evidence that improper purposes are playing a role" in government action. The manifestly defective process underlying Travel Ban 1.0 supports the lower courts' conclusion that the Orders here grew out of unlawful discriminatory intent, not actual national security need. And although the White House apparently brought more agencies into the fold in the lead-up to Travel Ban 2.0, the President himself called Travel Ban 2.0 a "watered down,

28 U.S. Dep't of Homeland Sec., Citizenship Likely an Unreliable Indicator of Terrorist Threat to the United States 1 [hereinafter Citizenship Likely an Unreliable Indicator]. 
politically correct version" of the first Order. ${ }^{29}$ White House political advisor Stephen Miller confirmed that Travel Ban 2.0 would reflect "mostly minor technical differences," yet achieve "the same basic policy outcome for the country," statements later echoed by other senior political officials. ${ }^{30}$

Finally, Travel Ban 3.0's generalized, countrybased approach remains virtually identical to its predecessors. This Ban includes a few new exceptions and names a slightly different list of countries, but still relies on sweeping and unprecedented nationality-based bans, directed at almost exclusively Muslim-majority countries, nearly all of which were on the prior lists. And unlike the earlier Orders, Travel Ban 3.0 is now indefinite. Whatever additional governmental process transpired plainly was not meant to alter the structure, substance, or purpose of the original Travel Ban 1.0.

As this Court reasoned in United States v. Fordice, 505 U.S. 717 (1992), "given an initially tainted policy, it is eminently reasonable to make the [Government] bear the risk of nonpersuasion with respect to intent at some future time, both because the [Government] has created the dispute through its own prior

29 Donald J. Trump (@realDonaldTrump), Twitter (June 5, 2017, 6:29 AM). Days following the issuance of Travel Ban 2.0, the President used the same language at a rally in Nashville, calling the Ban a "watered-down version of the first order." Jeremy Diamond, Trump Rails Against Court Ruling Blocking Travel Ban, CNN (Mar. 15, 2017).

30 Matthew Nussbaum et al., White House Creates Confusion About Future of Trump's Travel Ban, Politico (Feb. 21, 2017) (recounting similar statements by President Trump, Press Secretary Sean Spicer, and White House spokesman Michael Short). 
unlawful conduct, and because discriminatory intent does tend to persist through time." 31 At the very least, where-as here-there is (1) "a series of governmental actions,"32 (2) substantial similarity in form and effect between the earlier and later actions, ${ }^{33}$ and (3) evidence indicating that the original purpose of the policy remains a primary motivating factor, ${ }^{34}$ the passage of time and the government's tinkering on the margins should not cure the illegality. As Justice Thomas explained in Fordice, "[I]f a policy remains in force, without adequate justification and despite tainted roots ***, it appears clear-clear enough to presume conclusively - that the State has failed to disprove discriminatory intent."35

${ }^{31}$ Fordice, 505 U.S. at 746-47 (citations omitted).

32 McCreary, 545 U.S. at 866 (the government's argument "that purpose in a case like this one should be inferred, if at all, only from the latest news about the last in a series of governmental actions $* * * *$ just bucks common sense.").

${ }^{33}$ Fordice, 505 U.S. at 729 (invalidating Mississippi's re-classification of its state colleges and universities because, "[i]f policies traceable to the de jure system are still in force and have discriminatory effects, those policies too must be reformed to the extent practicable"); Hunter v. Underwood, 471 U.S. 222, 233 (1985) ("[W]e simply observe that its original enactment was motivated by a desire to discriminate against blacks on account of race and the section continues to this day to have that effect. As such, it violates equal protection under Arlington Heights.").

34 McCreary, 545 U.S. at 872 ("No reasonable observer could swallow the claim that the Counties had cast off the objective so unmistakable in the earlier displays.").

35 Fordice, 505 U.S. at 747 (Thomas, J., concurring). 


\section{B. The Orders do not advance the national security or foreign policy interests of the United States, and in fact do serious harm to those interests.}

Amici know of no national security or foreign policy interest that would justify Travel Ban 3.0. Amici include officials who were current on active intelligence concerning credible terrorist threat streams directed against the United States as recently as June 2017, five months after Travel Ban 1.0 was adopted. Yet amici are aware of no specific threat or deficiencies in the current visa vetting system that would justify the complete, country-wide suspensions of travel to the United States prescribed here. Travel Ban 3.0 not only fails to advance the national security or foreign policy interests of the United States, it harms those interests by taking discriminatory actions unprecedented in American history.

1. The Orders do not advance the national security or foreign policy interests of the United States.

Since the September 11, 2001 attacks, the United States has developed a rigorous system of security vetting, leveraging the full capabilities of the law enforcement and intelligence communities. This vetting is applied to individual travelers not once, but multiple times. As government officials, amici sought continually to improve that vetting, as was done in response to particular threats identified by U.S. intelligence in 2011 and 2015.36 Indeed, successive administrations have constantly worked to improve this vetting through robust information-sharing and data integration. And every one of these administrations did so

36 See infra text accompanying notes 66-70. 
without resorting as "leverage" to multiple, sweeping bans on travel for all citizens of any particular country.

Amici know of no evidence of a national security threat that would necessitate a sudden shift to a blanket national origin-based ban from the tested system of individualized vetting that had been developed and implemented by national security professionals across the government. ${ }^{37}$ Petitioners claim that Travel Ban 3.0 is needed "to encourage foreign governments to improve their information-sharing and identity-management protocols and practices." 38 But imposing a ban on all or most of the travelers from a group of countries in order to induce their governments to improve their information-sharing practices is an arbitrary and massively imprecise response to any concerns about information-sharing arrangements.

A sweeping national origin-based ban on travel is a remarkably overbroad and blunt mechanism for improving information sharing. In amici's experience, other countries are willing to cooperate with the United States to improve the exchange of necessary information. Occasionally, these countries may not be able to provide this information due to technological or resource limitations, but banning their citizens outright from coming to the United States will not solve those problems. In fact, such a ban is only likely to make information-sharing issues with a targeted country worse, by impairing economic and political

37 The Security of U.S. Visa Programs: Hearing Before the S. Comm. on Homeland Sec. and Governmental Affairs, 114th Cong. (2016) (written statements of David T. Donahue \& Sarah R. Saldaña).

38 Proclamation No. 9,645 (Sept. 24, 2017) [hereinafter Travel Ban 3.0]. 
interchange and spurring anti-American sentiment. For these reasons, no administration in history has resorted to this tool to achieve such a goal.

Notably, the individualized vetting system already requires that each specific visa applicant bear the burden of proving his or her identity and eligibility for entry into the United States before a visa is issued. ${ }^{39}$ Those visa applicants who cannot provide information or cannot be vetted are routinely denied. This has been the settled approach of the U.S. government across multiple administrations. For that reason, a country-based ban was hardly necessary, as Travel Ban 3.0 stated, to "protect the United States until such time as improvements occur." 40 Such protection was already provided by the pre-existing system of individualized vetting.

If the Ban's purpose is in fact to improve information-sharing protocols, it is also remarkably underinclusive. The Ban claims to reduce possible public safety threats posed by foreign nationals by excluding travelers who cannot be adequately vetted. However, the Ban does not remotely target all of the countries where there are deficiencies in identity-management. ${ }^{41}$ For example, all three Orders omitted Belgium, even though that nation has faced widely-documented problems with information sharing to the

\footnotetext{
398 U.S.C. $§ 1361$ (1996).

40 Travel Ban, 3.0, supra note 38.

${ }^{41}$ See, e.g., David Bier, Travel Ban Is Based on Executive Whim, Not Objective Criteria, Cato Institute: Cato at Liberty (Oct. 9, 2017).
} 
frustration of U.S. officials, and its nationals have carried out recent, deadly terrorist attacks in Europe. ${ }^{42}$

Further, there is no evidence that nationals of the banned countries who are allowed to enter the United States pose any credible threat to the safety of Americans. In fact, the Proclamation targets eight countries whose nationals have committed no deadly terrorist attacks on U.S. soil in the last forty years. ${ }^{43}$ Although Petitioners initially invoked the September 11 attacks as a rationale for Travel Ban 1.0,44 none of the September 11 hijackers were citizens of the countries listed in any of the Orders. ${ }^{45}$ And multiple analyses show that the overwhelming majority of individuals who have been charged with-or who died in the course of committing-terrorism-related crimes inside the United States since September 11 have not been citizens of foreign countries at all, but rather, U.S. citizens or legal permanent residents. ${ }^{46}$

${ }^{42}$ See, e.g., Mark Hosenball, U.S. Frustration Simmers Over Belgium's Struggle with Militant Threat, Reuters (Mar. 24, 2016); Andrew Higgins, Terrorism Response Puts Belgium in a Harsh Light, N.Y. Times (Nov. 24, 2015).

43 Alex Nowrasteh, President Trump's New Travel Executive Order Has Little National Security Justification, Cato Institute: Cato at Liberty (Sept. 25, 2017).

${ }^{44}$ Exec. Order No. 13,769, 82 Fed. Reg. 8977, §1 (Feb. 1, 2017) [hereinafter Travel Ban 1.0].

45 Peter Bergen et al., Terrorism in America After 9/11, New America Foundation (accessed Mar. 25, 2018).

46 See ibid.; Lorenzo Vidino \& Seamus Hughes, ISIS in America: From Retweets to Raqqa, Geo. Wash. Program on Extremism 7 (Dec. 2015); Nora Ellingsen, It's Not Foreigners Who Are Plotting Here: What the Data Really Show, Lawfare (Feb. 7, 2017); see also Lisa Daniels, Nora Ellingsen \& Benjamin Wittes, Trump Repeats His Lies About Terrorism, Immigration and Justice Department Data, Lawfare (Jan. 16, 2018); Alex Nowrasteh, 
Against this historical evidence, Petitioners offer no proof that the threat from the listed countries has suddenly increased so as to warrant the countrybased ban in Travel Ban 3.0. They do not cite any data, in either the Proclamation or their pleadings to this Court, that shows that nationals from these countries present a growing threat, or any particularized threat at all. Amici collectively know of no change in threat level that would justify the Proclamation's sweeping ban on travel for these countries.

In fact, when Travel Ban 2.0 called on the Department of Justice and the Department of Homeland Security to make available information on foreign

Terrorism and Immigration: A Risk Analysis, Cato Institute (Sept. 13, 2016); Felicia Schwartz \& Ben Kesling, Countries Under U.S. Entry Ban Aren't Main Sources of Terror Attacks, Wall St. J (Jan. 29, 2017). A March 2017 letter from then-Secretary of Homeland Security Kelly and Attorney General Sessions falsely claimed that since September 11, 2001, "a substantial majority of those convicted in U.S. courts for international terrorism-related activities were foreign-born." Exec. Order No. 13,780, 82 Fed. Reg. 13,209, §1(h) (Mar. 9, 2017) [hereinafter Travel Ban 2.0]; Letter from Jefferson B. Sessions III, Att'y Gen., \& John Francis Kelly, Sec'y of Homeland Sec., to Donald J. Trump, President (Mar. 6, 2017) [hereinafter March 6 Letter]. But this assertion referenced no underlying data, and has been widely criticized as inaccurate, and based on numerous apparent methodological flaws. See Nora Ellingsen \& Lisa Daniels, What the Data Really Show about Terrorists Who "Came Here," Lawfare (Apr. 11, 2017); Alex Nowrasteh, 42 Percent of "TerrorismRelated" Convictions Aren't for Terrorism, Cato Institute: Cato at Liberty (Mar. 6, 2017); Molly Redden, Trump Powers "Will Not be Questioned" on Immigration, Senior Official Says, The Guardian (Feb. 12, 2007); Shirin Sinnar, More Misleading Claims on Immigrants and Terrorism, Just Security (Mar. 4, 2017). See also Nora Ellingsen \& Benjamin Wittes, Anatomy of a Presidential Untruth: What Data Did the Justice Department Really Provide the White House?, Lawfare (Feb. 12, 2018). 
nationals who have been charged with terrorism-related offenses in the United States, the agencies responded with a report-which Petitioners choose not to cite-indicating that the federal government does not collect, maintain, or have access to the data that would be necessary to determine whether nationals from particular countries pose a greater terrorism threat to the United States. ${ }^{47}$ Thus, even when tasked, the responsible national security agencies themselves could not produce any data to support the claim that a country-based ban on travel was needed to protect against terrorist attacks.

2. The Orders do serious damage to the national security and foreign policy interests of the United States.

Travel Ban 3.0 not only fails to advance the national security or foreign policy interests of the United States; it causes multiple, serious harms to those interests.

First, Travel Ban 3.0 disrupts key counterterrorism, foreign policy, and national security partnerships. These partnerships are critical in maintaining the necessary collaboration channels in intelligence, law enforcement, military, and diplomacy to address the threat posed by terrorist groups such as the "Islamic State" (ISIS). The Ban has strained our

47 For example, the agencies advised that they were unable to provide compiled information about the "manner of entry into the United States, countries of origin, [or] general immigration histories" of the individuals convicted of international terrorism-related offenses since September 11, 2001. The information they were able to provide also excluded all domestic terrorism incidents. Protecting the Nation From Foreign Terrorist Entry Into the United States: Initial Section 11 Report (January 2018). See also Ellingsen \& Wittes, supra note 46. 
relationships with partner countries in Europe, Africa, and the Middle East on which we rely for vital counterterrorism cooperation, undermining years of effort to bring them closer. ${ }^{48}$

By alienating these partners, Travel Ban 3.0 has frustrated access to the intelligence and resources necessary to fight the root causes of terror, or to disrupt potential terror plots abroad before attacks occur within U.S. borders. For instance, Chad, a Muslimmajority country, pulled out of supporting anti-terrorism efforts in Niger shortly after being added to the list of banned countries in Travel Ban 3.0.49 Before this withdrawal, Chad had long been one of the United States' most effective counterterrorism partners in the African region. Chad was used as a staging ground by the U.S. Air Force in its surveillance of Boko Haram, hosted about 2,000 U.S. troops for an annual military exercise in March 2017, and served as the base of the Multinational Joint Task Force, the coordinated regional effort to fight Boko Haram. ${ }^{50}$

Second, the Ban endangers intelligence sources in the field. For up-to-date information, our intelligence officers often rely on human sources in some of the banned countries. The Ban breaches trust with those

${ }^{48}$ See, e.g., Helene Cooper et al., Chad's Inclusion in Travel Ban Could Jeopardize American Interests, Officials Say, N.Y. Times (Sept. 26, 2017); The International Implications of Trump's Refugee Ban, NPR (Jan. 29, 2017).

49 See Conor Gaffey, After Trump's Travel Ban, Chad Pulls Troops from Boko Haram Fight in Niger, Newsweek (Oct. 13, 2017); see also Helene Cooper et al., supra note 48.

50 See Kevin Sieff, Why Did the U.S. Travel Ban Add Count Terrorism Partner Chad? No One Seems Quite Sure, Wash. Post (Sept. 25, 2017); Krishnadev Calamur, Why Was Chad Included in the New Travel Ban?, The Atlantic (Sept. 26, 2017). 
very sources, who have put themselves at great risk to keep Americans safe-and whom our officers have promised to protect. ${ }^{51}$ Additionally, by suspending visas, this Ban halts the collection of vital intelligence that occurs during visa screening processes, information that can be used to recruit agents and identify regional trends of instability.

Third, the Ban feeds the recruitment narrative of ISIS and other extremists who portray the United States as engaging in a war on Islam. Because of its disparate impact on Muslim travelers and immigrants, the Ban fuels ISIS' narrative and send the wrong message to the Muslim community here at home and all over the world: that the U.S. government is hostile to them and their religion. ${ }^{52}$ The Ban also endangers Christian and other non-Muslim communities by handing ISIS a recruiting tool and propaganda victory that spreads their message that the United States is waging a religious war.

Fourth, the Ban disrupts ongoing law enforcement efforts. Domestic law enforcement relies heavily on partnerships with American Muslim communities to fight homegrown terrorism. ${ }^{53}$ By alienating MuslimAmerican communities in the United States, the Ban harms official efforts to enlist their assistance in identifying radicalized individuals who might initiate attacks such as those in San Bernardino and Orlando.

51 Michael V. Hayden, Opinion, Former CIA Chief: Trump's Travel Ban Hurts American Spies - and America, Wash. Post (Feb. 5, 2017).

52 See, e.g., Joby Warrick, Jihadist Groups Hail Trump's Travel Ban as a Victory, Wash. Post (Jan. 29, 2017).

${ }^{53}$ See, e.g., Kristina Cooke \& Joseph Ax, U.S. Officials Say American Muslims Do Report Extremist Threats, Reuters (June 16, 2016). 
Fifth, the Ban has disrupted our ongoing diplomatic efforts. The Ban has visibly compromised the ability of U.S. embassies in the listed countries to carry out their day-to-day functions. These embassies rely heavily on local employees, whose abilities to travel, or even to work at all, have been thrown into confusion by this Ban.

Sixth, the Ban has had a devastating humanitarian impact. The Travel Ban has disrupted the travel of numerous men, women, and children who have themselves been victimized by terrorists. ${ }^{54}$ Countless other travelers now face deep uncertainty about whether they will be able to travel to or from the United States for reasons including medical treatment, study or scholarly exchange, funerals, or other pressing family reasons. While the Ban allows the Secretaries of State and Homeland Security to admit travelers from targeted countries on a case-by-case basis, amici consider it unrealistic for these overburdened agencies to apply such procedures to each and every affected individual with urgent and compelling needs to travel. In fact, out of the more than 8,000 visa applicants from affected countries in the first month the Ban went into effect, only two applicants received waivers. ${ }^{55}$

Finally, the Ban affects many foreign travelers, who annually inject hundreds of billions of dollars into the U.S. economy, supporting well over a million

\footnotetext{
${ }^{54}$ See, e.g., Mallory Moench, Banned From the U.S. Due to Terrorist Threats, Yemenis Are Themselves the Victims of Attacks, The Intercept (Feb. 18, 2018).

55 Letter from Mary K. Waters, Assistant Sec'y, Legislative Affairs, to Chris Van Hollen, Senator (Feb. 22, 2018).
} 
U.S. jobs. ${ }^{56}$ This will have a negative impact on strategic economic sectors including defense, technology, and medicine. About one-third of U.S. innovators were born outside the United States, and their scientific and technological innovations have contributed to making our nation and the world safer. ${ }^{57}$ The unwarranted harm caused by the Ban to the economic dynamism of our country would carry long-term negative consequences for our national security.

The Ban's unprecedented scope only exacerbates these harms. In their long collective experience, amici know of no case where a President has invoked authority under the Immigration and Nationality Act to suspend admission of such a sweeping class of people. Even after the September 11 attacks, the U.S. government did not invoke the provisions of law cited by Petitioners to bar entrants based on nationality, national origin, or religious affiliation. To the contrary, across the decades, executive orders under the Immigration and Nationality Act usually have targeted specific government officials, ${ }^{58}$ undocumented immigrants, ${ }^{59}$ or other individuals whose personalized

56 U.S. Dep't of Commerce, Department of Commerce Releases October Travel and Tourism Expenditures (Dec. 15, 2016).

57 Adams Nager et al., The Demographics of Innovation in the United States, Information Technology \& Innovation Foundation 29 (Feb. 2016). See also Patrick O'Neill, How Academics Are Helping Cybersecurity Students Overcome Trump's Immigration Order, CyberScoop (Jan. 30, 2017).

58 See, e.g., Proclamation No. 6,958, 61 Fed. Reg. 60,007 (Nov. 22, 1996).

${ }^{59}$ See, e.g., Exec. Order No. 12,807, 57 Fed. Reg. 23,133 (May 24, 1992); Exec. Order No. 12,324, 46 Fed. Reg. 48,109 (Sept. 29, 1981). 
screenings indicated that as individuals, they posed national security risks. ${ }^{60}$

The two examples to which Petitioners pointCuba in $1986^{61}$ and Iran in 197962 - addressed an entirely different issue: bans on travel in the course of a bilateral diplomatic impasse to exert pressure on the opposing government to remove their own barriers on immigration, or cease their mistreatment of U.S. citizens. ${ }^{63}$ No President has ever used such a sweeping ban aimed at legal travelers to minimize a claimed security threat by the travelers themselves, or to induce other governments to improve their data management capabilities. And neither historic example approaches the sheer breadth of Travel Ban 3.0, which, with one stroke of the pen, indefinitely blocked as many as 180 million people or more ${ }^{64}$ in eight separate countries from traveling to the United States, based solely on their national origin. And the Ban contemplates that "additional countries" could join the list at some point in the future. 65

Nor can Travel Ban 3.0 be defended as a mere continuation of more recent U.S. counterterrorism policy.

${ }^{60}$ See, e.g., Exec. Order No. 13,726, 81 Fed. Reg. 23,559 (Apr. 19, 2016); Exec. Order No. 13,694, 80 Fed. Reg. 18,077 (Apr. 1, 2015).

61 Proclamation No. 5,517, 51 Fed. Reg. 30,470 (Aug. 22, 1986).

62 Exec. Order 12,172, 44 Fed. Reg. 67,947 (Nov. 26, 1979).

${ }^{63}$ Charles R. Babcock, Carter's Visa Crackdown Won't Hurt Immediately, N.Y. Times (Apr. 9, 1980); Gerald M. Boyd, Reagan Acts To Tighten Trade Embargo of Cuba, N.Y. Times (Aug. 23, 1986).

${ }^{64}$ David Bier, Prior Presidents' "Travel Bans" Are Different From President Trump's Ban, Cato Institute: Cato at Liberty (Nov. 16, 2017).

65 Travel Ban 3.0, supra note 38, at $§ 1(i)$. 
Because threat streams constantly evolve, while serving as national security officials, amici sought continually to improve vetting. That effort included reviews in 2011 and 2015-2016, when the U.S. government acted in response to particular threats identified by intelligence sources. In 2011, after receiving suspicious information regarding two Iraqi nationals who had entered the United States as refugees, the U.S. government undertook an extensive interagency review of the Iraqi refugee vetting system. ${ }^{66}$ During the pendency of that review, the flow of refugees from Iraq slowed but did not stop, ${ }^{67}$ and upon completion of the review, the U.S. government implemented new, stronger security procedures in areas of identified vulnerability. ${ }^{68}$

Likewise, in late 2015 and early 2016, in response to the emerging threat posed by ISIS, the U.S. government took several steps to strengthen the Visa Waiver Program, which allows citizens from thirty-eight approved countries to travel to the United States without first obtaining a visa. President Obama introduced a series of new measures to enhance security screenings and traveler risk assessments in the program and to bolster our relationship with partner

66 Jon Finer, Sorry, Mr. President: The Obama Administration Did Nothing Similar to Your Immigration Ban, Foreign Policy (Jan. 30, 2017).

67 U.S. Dep't of State, Bureau of Population, Refugees, and Migration, Refugee Arrivals, Interactive Reporting (2011), http://ireports.wrapsnet.org/; Finer, supra note 66.

68 Ten Years After 9/11: Preventing Terrorist Travel: Hearing Before the S. Comm. on Homeland Security and Governmental Affairs, 112th Cong. 122-127 (2011) (written statements of Rand Beers \& Janice L. Jacobs; Andorra Bruno, Cong. Research Serv., R43725, Iraqi and Afghan Special Immigrant Visa Programs, 14 (Feb. 26, 2016). 
countries. ${ }^{69}$ Around the same time, President Obama signed into law a statute that removed from the Visa Waiver Program those nationals of existing Visa Waiver Program countries who had been present in Iraq, Syria, Iran, or Sudan after March 1, 2011, or were dual nationals of one of those four countries. ${ }^{70}$ Several months later, the Secretary of Homeland Security-acting under the new statute and in consultation with the Director of National Intelligence and the Secretary of State - expanded the list to include persons who had traveled to Yemen, Libya, and Somalia.

These prior reforms provide no justification for a blanket, group-based ban on the entry of nationals from these eight countries. The enhancements introduced into the 2011 refugee system were designed to enable more searching, individualized vetting of travelers, the very opposite of the categorical ban in this Order. Similarly, the reforms to the Visa Waiver Program did not automatically bar anyone-including nationals of any country-from travel to the United States. Instead, the affected individuals no longer could automatically enter; they were simply required to obtain individually-vetted visas before entering the United States, in the same way as nationals of the more than 150 other nations that are not currently part of the Visa Waiver Program.

69 U.S. Dep't of Homeland Sec., DHS Announces Further Travel Restrictions for the Visa Waiver Program (Feb. 18, 2016); White House, Fact Sheet: Visa Waiver Program Enhancements (Nov. 30, 2015).

${ }^{70}$ Karoun Demirjian \& Jerry Markon, Obama Administration Rolls Out New Visa Waiver Program Rules in Wake of Terror Attacks, Wash. Post (Jan. 21, 2016). 


\section{Petitioners are unable to offer a credible national security or foreign policy ra- tionale for the Orders.}

Over the last fourteen months, Petitioners have offered a constantly shifting series of national security justifications for their generalized bans.

Travel Ban 1.0 included no public rationale for the ban at all, apart from suggesting that certain foreign individuals from these foreign countries were uniquely dangerous. The text of the Order made vague allusions to "numerous foreign-born individuals" who have been convicted or implicated in terrorism-related crimes, without tying these assertions to any of the seven listed countries. ${ }^{71}$

Travel Ban 2.0 shifted focus to the conditions in the listed countries, and their claimed inability to screen for terrorist groups, who might exploit their porous borders to slip through to the United States. The Order characterized each of the countries as a haven for terrorism or a place of active conflict, and argued that these circumstances increased the chance that "conditions will be exploited to enable terrorist operatives or sympathizers to travel to the United States."72 But as discussed supra, Petitioners offered no actual evidence that travelers from these countries present a particular risk to the United States of terrorist attacks. ${ }^{73}$

Perhaps for this reason, Travel Ban 3.0 changed course yet again. Petitioners have now removed the earlier emphasis on foreign nationals as terrorist

\footnotetext{
71 Travel Ban 1.0, supra note 44.

72 Travel Ban 2.0, supra note 46.

73 See supra notes 43-46 and accompanying text.
} 
threats, or on the listed countries as compromised by terrorism. Instead, claiming the vague purpose of addressing "security or public safety" threats, Travel Ban 3.0 posits that country-based bans on travel are necessary to induce those countries to "improve their information-sharing and identity-management protocols," as well as to advance other unspecified "foreign policy, national security and counterterrorism objectives." 74 From the beginning, this has always been a ban in search of a threat, not vice versa.

As Petitioners have cast about for a rationale for such a sweeping ban on travel, they have remained unable to adduce any credible information whatsoever in support of their shifting explanations. The text of Travel Ban 1.0 included no evidence at all, and Petitioners offered none in court. The text of Travel Ban 2.0 added language-now deleted from Travel Ban 3.0-from the 2015 Department of State Country Reports on Terrorism and other public reports generally discussing security conditions in the six listed countries, a thin reed on which to ban tens of millions of travelers. Petitioners also submitted at that time a vaguely worded two-page letter from the Secretary of Defense and the Secretary of Homeland Securitynow mentioned nowhere in their brief to this Courtthat discussed the risks of terrorism in general terms, but included no meaningful evidence justifying the need for a travel ban, much less any specific reference to the six countries at all. ${ }^{75}$

74 Travel Ban 3.0, supra note 38.

${ }^{75}$ See March 6 Letter, supra note 46 . Without providing any citations, data, or other supporting evidence for its assertions, the letter simply claimed that "based on DHS data and the experience of its operators, nationals from these countries are more likely to overstay their visas and are harder to remove to their 
Fourteen months on, Petitioners still offer this Court no credible information in defense of Travel Ban 3.0. The Proclamation itself mechanically asserts that the listed countries do not share information, while providing no evidence of any specific threat or harm that can be tied to a particular country's deficiencies, or that if allowed to enter the United States, any particular nationals from the banned countries would pose a credible threat to the safety of Americans. ${ }^{76}$ Although the Proclamation references a new report that it says drove its conclusions, Petitioners do not provide it, draw from it, or even cite it in their brief. 77

Perhaps most remarkable, Petitioners remain unable to produce a single official willing to swear on the record to a national security-based need for Travel Ban 3.0, or the process that led to its creation. As the Court well knows, in countless prior cases where the

home countries," and "there is a greater risk that the United States will not have access to necessary records." Ibid. It remains unclear whether the above statement was alluding to the six listed countries in Travel Ban 2.0, or instead to the broader group of all countries that, in the words of the letter, are deemed "state sponsors of terrorism, or ... have active conflict zones in which the central government has lost control of territory to terrorists." Ibid; see U.S. Dep't of State, Country Reports on Terrorism 2015, Chapter 5: Terrorist Safe Havens (Update to 7120 Report) (listing more than a dozen countries or regions as "terrorist safe havens," defined as "ungoverned, under-governed, or ill-governed physical areas where terrorists are able to organize *** in relative security because of inadequate governance capacity, political will, or both”). See also supra note 46.

76 Travel Ban 3.0, supra note 38.

77 Petitioners even told the district court in this very case that they did not intend to rely on the report in defense of the Order. Notice of In Camera, Ex Parte Lodging of Report, State of Hawai'i v. Trump, No. 17-cv-00050 (Dec. 13, 2017). 
Executive Branch has faced a legal challenge to a significant national security initiative, it has submitted into the record at least one sworn declaration from a federal official that seeks to explain the motivation and origins of the challenged policy. ${ }^{78}$ Indeed, this Administration has followed that same standard practice when its other immigration policies have faced substantial constitutional and statutory challenges. ${ }^{79}$ Yet here, after more than a year of litigation, Petitioners still have not proffered a single national security official who will so attest in defense of the broadest travel ban in American history. ${ }^{80}$

${ }^{78}$ See, e.g., Unclassified Declaration in Support of Formal Claim of State Secrets Privilege by James R. Clapper, Director of Nat'l Intelligence, Al-Aulaqi v. Obama, 727 F.Supp.2d 1 (D.D.C. 2010) (No. 1:10-cv-01469) (explaining the Government's rationale for targeting Anwar al-Aulaqi); Declaration by Brigadier General Jay Hood, Hamdan v. Rumsfeld, 341 F.Supp.2d 152 (D.D.C. 2004) (No. 1:04-cv-01519) (defending the detention and interrogation practices at Guantánamo Bay).

${ }^{79}$ For example, when the Secretary of State, Acting Secretary of Homeland Security, and Director of National Intelligence issued a Joint Memorandum in October 2017 imposing an indefinite pause on "follow-to-join" refugee applications, Petitioners submitted a sworn declaration from a senior DHS official describing the claimed rationale for the change. See Decl. of Jennifer B. Higgins in Support of Defendant's Opposition to Plaintiff Joseph Doe's Motion for Preliminary Injunction, Doe v. Trump, No. 2:17cv-00178 JLR (W.D. Wash. 2017).

${ }^{80}$ Petitioners did offer a sworn declaration on behalf of a Department of State official in defense of the separate refugee ban in Travel Ban 2.0 not at issue here. But even that declaration meticulously avoided defending the substance, process, or rationale for the Refugee Ban, instead confining itself to giving background information on the U.S. refugee process. Decl. of Lawrence E. Bartlett, State v. Trump, 263 F. Supp. 3d 1049 (D. Haw.), aff'd, 871 F.3d 646 (9th Cir. 2017). 
Finally, in this case, Petitioners' own actions show that even they never took their own assertions of national security urgency seriously. Travel Ban 1.0 suspended travel from the listed countries for 90 days. The Order directed named officials within the first 30 days to complete a review of existing protocols, to report to the President on that review, and then to start making the necessary requests to foreign governments to begin providing requested information. ${ }^{81}$ But after 47 days (between the travel ban going into effect and the review process being blocked by the U.S. District Court for the District of Hawaii), Petitioners admitted to having done only "some work" on the very first stage of the review-report-request process described in the initial Order. ${ }^{82}$ Petitioners' unhurried implementation further undermines their current claim that their unprecedented, sweeping ban on travel was driven by some urgent national security need.

$$
* * *
$$

Ours is a nation of immigrants, committed to the faith that we are all equal under the law, and rejecting discrimination, whether based on race, religion, sex, or national origin. As government officials, amici sought diligently to protect our country, while maintaining an immigration system that is as free as possible from prejudice, that applies no religious tests, and that measures individuals by their merits, not stereotypes of their countries or groups.

Blanket bans of certain countries or classes of people are beneath the dignity of the Nation and

81 Travel Ban 1.0, supra note 44, at $§ 3$.

82 Oral Argument at 8:10, Int'l Refugee Assistance Project v. Trump, 857 F.3d 554 (4th Cir. May 8, 2017) (No. 17-1351). 
Constitution that we each took oaths to protect. Rebranding a proposal first advertised as a "Muslim Ban" as "Protecting the Nation from Foreign Terrorist Entry into the United States" does not disguise the Order's discriminatory intent, or make it necessary, effective, or faithful to America's Constitution, laws, or values.

\section{CONCLUSION}

For the foregoing reasons, this Court should affirm the opinion of the U.S. Court of Appeals for the Ninth Circuit.

\begin{tabular}{ll}
\multicolumn{2}{c}{ Respectfully submitted, } \\
PHILLIP SPECTOR & HAROLD HONGJU KOH \\
Messing \& Spector LLP & Counsel of Record \\
1200 Steuart Street & MATTHEW S. BLUMENTHAL \\
\#2112 & Rule of Law Clinic \\
Baltimore, MD 21230 & Yale Law School \\
(202) 277-8173 & 127 Wall Street \\
JONATHAN FREIMAN & P.O. Box 208215 \\
TAHLIA TOWNSEND & New Haven, CT 06520 \\
Wiggin and Dana LLP & (203) 432-4932 \\
265 Church Street & harold.koh@ylsclinics.org \\
P.O. Box 1832 & WILLIAM J. MURPHY \\
New Haven, CT & JOHN J. CONNOLLY \\
06508-1832 & Zuckerman Spaeder LLP \\
(203) 498-4584 & 100 E. Pratt St. \\
& Suite 2440 \\
& Baltimore, MD 21202 \\
& (410) 332-0444
\end{tabular}


APPENDIX 


\section{APPENDIX}

\section{List of Amici Curiae}

1. Madeleine K. Albright served as Secretary of State from 1997 to 2001. A refugee and naturalized American citizen, she served as U.S. Permanent Representative to the United Nations from 1993 to 1997. She has also been a member of the Central Intelligence Agency External Advisory Board since 2009 and of the Defense Policy Board since 2011, in which capacities she has received assessments of threats facing the United States.

2. Rand Beers served as Deputy Homeland Security Advisor to the President of the United States from 2014 to 2015.

3. John B. Bellinger III served as the Legal Adviser for the U.S. Department of State from 2005 to 2009. He previously served as Senior Associate Counsel to the President and Legal Adviser to the National Security Council from 2001 to 2005.

4. Daniel Benjamin served as Ambassador-at-Large for Counterterrorism at the U.S. Department of State from 2009 to 2012.

5. Antony Blinken served as Deputy Secretary of State from 2015 to January 20, 2017. He previously served as Deputy National Security Advisor to the President of the United States from 2013 to 2015. 
6. John O. Brennan served as Director of the Central Intelligence Agency from 2013 to 2017. He previously served as Deputy National Security Advisor for Homeland Security and Counterterrorism and Assistant to the President from 2009 to 2013.

7. R. Nicholas Burns served as Under Secretary of State for Political Affairs from 2005 to 2008. He previously served as U.S. Ambassador to NATO and as U.S. Ambassador to Greece.

8. William J. Burns served as Deputy Secretary of State from 2011 to 2014. He previously served as Under Secretary of State for Political Affairs from 2008 to 2011, as U.S. Ambassador to Russia from 2005 to 2008, as Assistant Secretary of State for Near Eastern Affairs from 2001 to 2005, and as U.S. Ambassador to Jordan from 1998 to 2001.

9. James Clapper served as U.S. Director of National Intelligence from 2010 to January 20, 2017.

10. David S. Cohen served as Under Secretary of the Treasury for Terrorism and Financial Intelligence from 2011 to 2015 and as Deputy Director of the Central Intelligence Agency from 2015 to January $20,2017$.

11. Eliot A. Cohen served as Counselor of the U.S. Department of State from 2007 to 2009. 
12. Bathsheba N. Crocker served as Assistant Secretary of State for International Organization Affairs from 2014 to 2017.

13. Ryan Crocker served as U.S. Ambassador to Afghanistan from 2011 to 2012, as U.S. Ambassador to Iraq from 2007 to 2009, as U.S. Ambassador to Pakistan from 2004 to 2007, as U.S. Ambassador to Syria from 1998 to 2001, as U.S. Ambassador to Kuwait from 1994 to 1997, and U.S. Ambassador to Lebanon from 1990 to 1993.

14. Thomas Donilon served as U.S. National Security Advisor from 2010 to 2013.

15. Jen Easterly served as Special Assistant to the President and Senior Director for Counterterrorism from October 2013 to December 2016.

16. Daniel Feldman served as U.S. Special Representative for Afghanistan and Pakistan from 2014 to 2015, Deputy U.S. Special Representative for Afghanistan and Pakistan from 2009 to 2014, and previously Director for Multilateral and Humanitarian Affairs at the National Security Council.

17. Jonathan Finer served as Chief of Staff to the Secretary of State from 2015 until January 20, 2017, and Director of the Policy Planning Staff at the U.S. Department of State from 2016 to January 20, 2017.

18. Michèle Flournoy served as Under Secretary of Defense for Policy from 2009 to 2013. 
19. Robert S. Ford served as U.S. Ambassador to Syria from 2011 to 2014, as Deputy Ambassador to Iraq from 2009 to 2010, and as U.S. Ambassador to Algeria from 2006 to 2008.

20. Josh Geltzer served as Senior Director for Counterterrorism at the National Security Council from 2015 to 2017. Previously, he served as Deputy Legal Advisor to the National Security Council and as Counsel to the Assistant Attorney General for National Security at the Department of Justice.

21. Suzy George served as Deputy Assistant to the President and Chief of Staff and Executive Secretary to the National Security Council from 2014 to 2017.

22. Phil Gordon served as Special Assistant to the President and White House Coordinator for the Middle East, North Africa and the Gulf from 2013 to 2015, and Assistant Secretary of State for European and Eurasian Affairs from 2009 to 2013.

23. Chuck Hagel served as Secretary of Defense from 2013 to 2015, and previously served as Co-Chair of the President's Intelligence Advisory Board. From 1997 to 2009, he served as U.S. Senator for Nebraska, and as a senior member of the Senate Foreign Relations and Intelligence Committees.

24. Avril D. Haines served as Deputy National Security Advisor to the President of the United States from 2015 to January 20, 2017. From 
2013 to 2015, she served as Deputy Director of the Central Intelligence Agency.

25. Luke Hartig served as Senior Director for Counterterrorism at the National Security Council from 2014 to 2016.

26. General (ret.) Michael V. Hayden, USAF, served as Director of the Central Intelligence Agency from 2006 to 2009. From 1995 to 2005, he served as Director of the National Security Agency.

27. Heather A. Higginbottom served as Deputy Secretary of State for Management and Resources from 2013 to 2017.

28. Christopher R. Hill served as Assistant Secretary of State for East Asian and Pacific Affairs from 2005 to 2009. He also served as U.S. Ambassador to Macedonia, Poland, the Republic of Korea, and Iraq.

29. John F. Kerry served as Secretary of State from 2013 to January 20, 2017.

30. Prem Kumar served as Senior Director for the Middle East and North Africa on the National Security Council staff of the White House from 2013 to 2015 .

31. Richard Lugar served as U.S. Senator for Indiana from 1977 to 2013, and as Chairman of the Senate Committee on Foreign Relations from 1985 to 1987 and 2003 to 2007, and as ranking 
member of the Senate Committee on Foreign Relations from 2007 to 2013.

32. John E. McLaughlin served as Deputy Director of the Central Intelligence Agency from 2000 to 2004 and as Acting Director in 2004. His duties included briefing President-elect Bill Clinton and President George W. Bush.

33. Lisa O. Monaco served as Assistant to the President for Homeland Security and Counterterrorism and Deputy National Security Advisor from 2013 to January 20, 2017.

34. Cameron P. Munter served as U.S. Ambassador to Pakistan from 2009 to 2012 and to Serbia from 2007 to 2009 .

35. James C. O'Brien served as Special Presidential Envoy for Hostage Affairs from 2015 to January 20, 2017. He served in the U.S. Department of State from 1989 to 2001, including as Principal Deputy Director of Policy Planning and as Special Presidential Envoy for the Balkans.

36. Matthew G. Olsen served as Director of the National Counterterrorism Center from 2011 to 2014.

37. Leon E. Panetta served as Secretary of Defense from 2011 to 2013 . From 2009 to 2011, he served as Director of the Central Intelligence Agency. 
38. Anne W. Patterson served as Assistant Secretary of State for Near Eastern Affairs from 2013 to 2017. Previously, she served as the U.S. Ambassador to Egypt, 2011 to 2013, to Pakistan, 2007 to 2010, to Colombia, 2000 to 2003, and to El Salvador, 1997 to 2000 .

39. Jeffrey Prescott served as Special Assistant to the President and Senior Director for Iran, Iraq, Syria and the Gulf States from 2015 to 2017.

40. Samantha J. Power served as U.S. Permanent Representative to the United Nations from 2013 to January 20, 2017. From 2009 to 2013, she served as Senior Director for Multilateral and $\mathrm{Hu}$ man Rights on the National Security Council.

41. Susan E. Rice served as U.S. Permanent Representative to the United Nations from 2009 to 2013 and as National Security Advisor from 2013 to January 20, 2017.

42. Anne C. Richard served as Assistant Secretary of State for Population, Refugees and Migration from 2012 to January 20, 2017.

43. Kori Schake served as the Deputy Director for Policy Planning at the U.S. Department of State from December 2007 to May 2008. Previously, she was the director for Defense Strategy and Requirements on the National Security Council in President George W. Bush's first term.

44. Eric P. Schwartz served as Assistant Secretary of State for Population, Refugees and 
A-8

Migration from 2009 to 2011. From 1993 to 2001, he was responsible for refugee and humanitarian issues on the National Security Council, ultimately serving as Special Assistant to the President for National Security Affairs and Senior Director for Multilateral and Humanitarian Affairs.

45. Wendy R. Sherman served as Under Secretary of State for Political Affairs from 2011 to 2015.

46. Vikram Singh served as Deputy Special Representative for Afghanistan and Pakistan from 2010 to 2011 and as Deputy Assistant Secretary of Defense for Southeast Asia from 2012 to 2014.

47. Dana Shell Smith served as U.S. Ambassador to Qatar from 2014 to 2017. Previously, she served as Principal Deputy Assistant Secretary of Public Affairs.

48. Jeffrey H. Smith served as General Counsel of the Central Intelligence Agency from 1995 to 1996. Previously, he served as General Counsel of the Senate Armed Services Committee.

49. James B. Steinberg served as Deputy National Security Adviser from 1996 to 2000 and as Deputy Secretary of State from 2009 to 2011.

50. Linda Thomas-Greenfield served as Assistant Secretary for the Bureau of African Affairs from 2013 to 2017. Previously she served as U.S. Ambassador to Liberia and Deputy Assistant 


\section{A-9}

Secretary for the Bureau of Population, Refugee and Migration from 2004 to 2006.

51. William Wechsler served as Deputy Assistant Secretary for Special Operations and Combating Terrorism at the U.S. Department of Defense from 2012 to 2015.

52. Samuel M. Witten served as Principal Deputy Assistant Secretary of State for Population, Refugees, and Migration from 2007 to 2010 . From 2001 to 2007, he served as Deputy Legal Adviser at the State Department. 